\title{
The Effect of Using Smart Board on Mathematics Achievement and Retention of Seventh Grade Students
}

\author{
Khamis Mousa Nejem ${ }^{1, *} \&$ Wafa Muhanna ${ }^{1}$ \\ ${ }^{1}$ Department of Curricula and Instruction, Faculty of Educational Sciences, Al al-Bayt \\ University, Jordan \\ *Corresponding author: Department of Curricula and Instruction, Faculty of Educational \\ Sciences, Al al-Bayt University, Jordan. E-mail: khnejem@yahoo.com
}

Received: April 2, 2014 Accepted: May 12, 2014 Published: December 9, 2014

doi:10.5296/ije.v6i4.6753 URL: http://dx.doi.org/10.5296/ije.v6i4.6753

\begin{abstract}
The purpose of the study is to investigate the effect of using smart board on mathematics achievement and retention of seventh grade students. To achieve this purpose a study sample of (103) students was selected from the seventh grade. This sample was divided into two groups. One group was randomly chosen to be the experimental group that studied mathematics using smart board; the other was the control group that studied mathematics using traditional method and board. The instrument of the study was an achievement test which was used to measure mathematics achievement and retention of the students. Data analysis procedures using T-test for independent samples revealed a positive effect of using smart board on students` achievement and retention in mathematics.
\end{abstract}

Keywords: Smart board, mathematics achievement, mathematics retention. 


\section{Introduction}

Technology has become an essential tool for doing mathematics in today's world. It can be used in a variety of ways to improve and enhance the learning of mathematics. As NCTM (2000) highlights in its standards, technology can facilitate mathematical problem solving, communication, reasoning, and proof; moreover, technology can provide students with opportunities to explore different representations of mathematical ideas and support them in making connections both within and outside of mathematics (Niess,2006). The research literature provides supporting evidence that the use of technology has enabled students to visualize mathematics, engage in active learning strategies, verify conjectures, have positive attitudes, and build confidence in their ability to do mathematics (Kersaint, 2007).

This call to integrate technology into mathematics education challenges not only school mathematics, but also preservice and in-service mathematics education of teachers. Mathematics teacher educators are challenged with the task of preparing teachers who can utilize technology as an essential tool in developing a deep understanding of mathematics for themselves and for their students. Recent trends in teacher education have emphasized the importance of learning with technology rather than learning about technology (Li, 2003).

Teacher preparation programs need to focus on strengthening the preservice teachers' knowledge of how to incorporate technology to facilitate student learning of mathematics through experiences that (Niess, 2006):

- Allow teacher candidates to explore and learn mathematics using technology in ways that build confidence and understanding of the technology and mathematics.

- Model appropriate uses of a variety of established and new applications of technology as tools to develop a deep understanding of mathematics in varied contexts.

- Help teacher candidates make informed decisions about appropriate and effective uses of technology in the teaching and learning of mathematics.

- Provide opportunities for teacher candidates to develop and practice teaching lessons that take advantage of the ability of technology to enrich and enhance the learning of mathematics.

One of the new technological advancements that is widely used in the classroom nowadays is a smart board to increase a student's knowledge and motivation (Rakes et al., 2006; Siemens and Matheos, 2010; Knezek et al., 2006). The technological capabilities of the smart board and its attendant software are highly compelling to students, effectively drawing them into the content of the lesson. Investment of financial and human resources in smart board technology is seen as warranted in part because it promises to make learning more engaging for students, especially in technical subjects (e.g., mathematics) in which teachers sometimes struggle in their efforts to help students engage and achieve (Torff \& Tirotta, 2010).

Interactive smart boards have gained a reputation in the educational system from the first grade to the university stage (Bell, 2002; Oigara, 2010). Cognitive research has shown that learning is most effective when four fundamental characteristics are present: active 
engagement, participation in groups, frequent interaction and feedback, and connection to real-world contexts (Roschelle et al., 2000). Research in educational technology has shown that combining smart boards with computer use increases the interactive atmosphere in the classroom (Carbonara, 2005; Oigara \& Keengwe, 2011). The interactive quality of a smart board lends itself to a degree of student participation not offered by other presentation methods. Certain factors play a major role in how smart boards are used in education and are sometimes called "contextual factors". The most common contextual factors include school culture, teacher training, time to practice and prepare materials, teacher confidence, and technical support (Digregorio \& Sobel-Lojeski, 2010).

The smart board is made up of a computer, smart board software, an interactive whiteboard, and a projector. The smart board interactive whiteboard system is made up of a computer with the smart board software, a projector and the smart board interactive whiteboard itself. "With a touch of a finger, students can control applications; navigate the Internet; and write, change, move around, and save content" (Sani, 2007). The entire premise of this technology is built upon active engagement. Touch-sensitive screens are mounted on the wall of the classroom and a projector shows information that can be manipulated and displayed with unlimited capabilities. The advantage of smart board technology is its design for use in a spacious work area with group interaction. The enlarged visuals are easily seen due to the size of the interactive whiteboard. Participants become both visually and physically engaged as they connect with electric content and multimedia in a collaborative learning environment (Smart Technologies, 2004).

Applications of the smart board are dependent on the software that is installed and used on the computer connected to the smart board. Some of the many applications available include hiding and revealing, writing and manipulating text, handwriting recognition, saving, retrieving, and printing notes, capturing and manipulating web content, shading, coloring, and animation. In addition, more recent smart board software allows the teacher to connect over the Internet to a library of subject specific flash content like a virtual calculator, virtual frog dissector, interactive maps, and more. Many libraries are located at the smart board manufacturer's website, so that content can be added on a regular basis, giving teachers more options (Digregorio \& Sobel-Lojeski, 2010).

Using special pens, students and/or teachers write directly on the screen. They can manipulate text and images, view websites, cut and paste research information, view video clips, formulate graphs and charts, and design vivid and creative presentations. Students combine their cognitive and physical abilities to interact with smart board technology. The interactive nature of the technology and the state-of-the art software enable students to generate activities that are engaging, useful, and enlightening. Informational text, research, and real-time Internet sites can be easily incorporated and accessed during the lesson (Starkman, 2006).

Additional interactive features include the conversion of handwritten text to typewritten text, drag and drop boxes, the opportunity to highlight specific words, and the option of diagramming/scaffolding information. Teachers can download lesson plans, adjust them to 
the specific needs of the students, and save them for future use. When learning with a smart board, students are engaged and listening instead of taking notes. Taking notes is distracting and does not allow the students to learn to their full potential. While the lesson is going on, the students are engaged in learning and teachers are able to send the notes to the students at a later time so that they can review on their own. This is an example of technology being put to good use and reaching students at different levels of learning.

Research on the use of interactive smart boards in education has expanded in the last decade as the emphasis in education spending and curriculum planning has extended to specifically recognize the importance of skills in information and communication technology (Hall \& Higgins, 2005; Manitoba Education \& Training, 1998). The research has included specific examination of implementation at the broadest level in terms of the type of equipment that may offer the greatest benefit for enhancing education to specific examination of the use of interactive whiteboard technology for the teaching of specific topics (Rudd, 2007; Shenton \& Pagett, 2007).

Furthermore, research has included examination of the specific perceptions of students and teachers regarding the use of smart boards within the classroom. Research has consistently shown that students and teachers alike perceive that this technology offers considerable benefits to enhance students' attention to the task at hand and may even improve their ability to learn the material (Hall et al., 2005; Miller \& Glover, 2002; Reimer \& Moyer, 2005). In contrast, the use of this technology offers benefits for teachers with respect to professionalism of the presentations they develop, the efficiency with which they can deliver a lesson, and diversity in terms of the manner in which they present curriculum content (Rudd, 2007).

Broader discussions of the use of smart boards in the classroom have examined whether the presence of technology contributes to a more dynamic classroom environment or whether it creates conditions that place the teacher (using the board) as the focal point of the learning context rather than promoting interaction within the classroom between students and the teacher and students (Rudd, 2007). In fact, Shenton and Pagett (2007) reported that some teachers who used the interactive whiteboards were most concerned about creating interactivity between the students and the board itself rather than between members of the classroom. The question is whether, as teachers are integrating the technology into the classroom, they are using it in a way that enhances the dynamic nature of instruction or disrupting it. Is there evidence that teachers use smart boards, as Burden (2002) suggests, in a way that creates conditions for learners to be passive or in a way that adds value to the learning process? In his study, he examined the experiences of nine grade 6 teachers as they developed their skills in the use of an interactive whiteboard in their classrooms, particularly for teaching science. He was particularly interested how they perceived the potential use of the board and how they implemented it in their classroom instruction.

The results of studies indicated that the use of smart boards has a positive effect on student engagement, and both students and teachers have generally positive attitudes toward the use of smart boards in teaching process and they are both aware of the potential uses of this technology (Gregory, 2010;Aytac,2013; Digregorio and Sobel-Lojeski, 2010). 
Torff and Tirotta (2010) conducted study to determine the extent to which use of interactive whiteboard technology (IWB) was associated with upper elementary students' self-reported level of motivation in mathematics. The study's participants included 773 students (241 students in 4th grade, 260 in 5th grade, and 232 in 6th grade). There were 32 participating teachers: 19 who indicated they were IWB users (the treatment group) and 13 who indicated that they were not extensive users of the IWB (the control group). The treatment group included 458 students and the control group had 315 students. The results of the study revealed that the students in the treatment group reported higher levels of motivation relative to control students. Students with teachers who were more supportive of IWB technology reported higher motivation levels (compared to students of teachers who were less supportive).

Wall et al. (2005) conducted survey research in which 80 students filled out templates with questions that asked them what they thought of the IWB and what they were likely to share with others about this technology. A total of 1568 responses were analyzed; 883 of the statements were judged to be positive, 494 statements were scored as neutral, and 191 were judged to be negative. Positive statements were then broken down into subcategories, with "motivation" and "fun" each noted in over 120 responses. The researchers concluded that students deemed the IWB to be motivational and fun, especially when students were able to see their work projected on the IWB screen.

The study of Aytac (2013) investigated the students' viewpoints and the problems they face during the use of Interactive Whiteboard (IWB). This research has been applied on 202 students in primary school and high school in Ankara. In this study, the quantitative data were collected through "IWB Survey Questions" (Student Views). To identify any significant differences in terms of gender and duration of using IWB for students' views, t-test and one-way ANOVA were used. No significant differences were found in terms of gender. There is a clear difference between primary school and high school students' views about the use of IWB. During this study it was observed that students generally had a positive attitude towards the use of IWB. Students identified teachers' inefficiency to use IWB, technical problems, insufficiency of e-materials and their wonders about the radiation and eye health as problems.

\section{Problem of the study}

One of the new technological advancements that is widely used in the classroom nowadays is a smart board. The current study tried to investigate the effect of using smart board in teaching mathematics on mathematics achievement and retention of seventh grade students.

\section{Questions of the study}

1. What is the effect of using smart board on mathematics achievement of seventh grade students? 


\section{Macrothink}

2. What is the effect of using smart board on mathematics retention of seventh grade students?

\section{Hypotheses of the study}

1. There is no statistical significant difference $(\alpha=0.05)$ in mathematics achievement test between the experimental group that studied mathematics using smart board, and the control group that studied mathematics using traditional method and board.

2. There is no statistical significant difference $(\alpha=0.05)$ in mathematics retention test between the experimental group that studied mathematics using smart board, and the control group that studied mathematics using traditional method and board.

\section{Terms of the study}

\subsection{Smart board}

Hardware and software programs are combined by the smart board to create an interactive whiteboard that allows presenters to display and manipulate information on the board for the audience to view. The board operates by touch or by pens that are provided with the board. The smart board was used in teaching the geometry unit from the seventh grade mathematics textbook.

\subsection{Mathematics achievement}

The total marks obtained by the student in mathematics achievement test directly after finishing the experiment.

\subsection{Mathematics retention}

The total marks obtained by the student in mathematics achievement test after four weeks from finishing the experiment.

\section{The study limitations}

The mathematics achievement and retention of the students were measured through an achievement test prepared by the researchers, so the results are connected to the test questions from its validity and suitability to the subject.

\section{Method and procedures}

\subsection{The study population}

The population of the study included all of the seventh grade students in the governmental male schools of Education Directorate in the first Amman region in Amman city in Jordan, 
who are attending the schools in the second semester of the scholastic year 2012/2013, their number is (3941) students.

\subsection{The study sample}

The study sample consisted of (103) seventh grade students. This sample was divided into two groups. One group was randomly chosen to be the experimental group (consisted of 52 students) that studied mathematics using smart board, the other was the control group (consisted of 51 students) that studied mathematics using traditional method and board.

\subsection{Instrument of the study}

The instrument of the study was an achievement test which was used to measure mathematics achievement and retention of the students in the geometry unit from the seventh grade mathematics textbook. This test was prepared by the researchers themselves, it consisted of essay and subjective questions.

To ensure the test validity, the questions of the test were presented to several experts specialist in mathematics curricula and educational psychology from the professors in the Jordanian universities. The necessary changes were done according to the suggestions and the remarks of the judges, so the final form of the test has done. The total mark of the test was (30).

To ensure the test reliability, the researchers applied it to a pilot sample of (41) students excluded of the study sample with a two-week period between the first and second time it was applied. The reliability of the test was calculated using correlation coefficient and it was found (0.82) which is suitable for conducting such a study.

\subsection{Procedures of the study}

The study has been accomplished in the following steps:

- After choosing the study sample, the teacher was trained to do the procedures in using the smart board in teaching mathematics, and testing these procedures on a pilot sample to solve problems that might show during the execution.

- Before executing the experiment, the achievement pre-test was applied to both the control group and the experimental group and that is to check the equivalence of the two groups in the mathematics achievement before executing the experiment.

- The study was executed during the second semester of the scholastic year 2012/2013 were the experimental group studied using smart board and the control group studied using the traditional method and board.

- After two days from finishing the experiment, the achievement post-test was applied on both groups to answer the first question of the study and testing its first hypothesis, and the students were told the test date.

- After four weeks from finishing the experiment, the achievement test was applied on both groups to answer the second question of the study and testing its second hypothesis, and 
without telling the students the test date.

\subsection{Statistical analysis}

To answer the questions of the study and testing its hypotheses, SPSS statistical program for social sciences was used. The following statistical analyses were used: means, standard deviations and T-test for independent samples.

\section{Results}

\subsection{The results related to the achievement pre-test}

Before executing the experiment, the achievement pre-test was applied to both the control group and the experimental group and that is to check the equivalence of the two groups in the mathematics achievement before executing the experiment. Means and standard deviations were calculated, then T-test for independent samples was used, the following results have been reached and illustrated in table 1.

Table 1. The results of T-test for independent samples to compare between the means of the control and the experimental groups in the achievement pre-test

\begin{tabular}{lllcccc}
\hline Group & Number & Mean & $\begin{array}{c}\text { Std. } \\
\text { Deviation }\end{array}$ & $\begin{array}{c}\text { Degree of } \\
\text { freedom }\end{array}$ & $\begin{array}{c}\text { Value } \\
\text { of (T) }\end{array}$ & $\begin{array}{c}\text { Statistical } \\
\text { significance }\end{array}$ \\
\hline Control & 51 & 5.18 & 1.64 & 101 & 0.787 & 0.413 \\
Experimental & 52 & 4.92 & 1.71 & & & \\
\hline
\end{tabular}

Table 1 shows that there is no statistically significant difference between the means of the control and the experimental groups in the achievement pre-test, where calculated $(\mathrm{T})$ has no statistical significance at the level of significance $(\alpha=0.05)$. We conclude that the two groups are equivalent in the mathematics achievement before executing the experiment.

8.2 The results related to the first question: What is the effect of using smart board on mathematics achievement of seventh grade students?

To answer the first question of the study, the achievement post-test was applied to both the control group and the experimental group. Means and standard deviations were calculated, then T-test for independent samples was used, the following results have been reached and illustrated in table 2 .

Table 2. The results of T-test for independent samples to compare between the means of the control and the experimental groups in the achievement post-test

\begin{tabular}{lcccccc}
\hline Group & Number & Mean & $\begin{array}{c}\text { Std. } \\
\text { Deviation }\end{array}$ & $\begin{array}{c}\text { Degree } \\
\text { of } \\
\text { freedom }\end{array}$ & $\begin{array}{c}\text { Value } \\
\text { of (T) }\end{array}$ & $\begin{array}{c}\text { Statistical } \\
\text { significance }\end{array}$ \\
\hline Control & 51 & 18.59 & 6.17 & 101 & 3.663 & $0.000 *$ \\
Experimental & 52 & 22.78 & 5.42 & & &
\end{tabular}




\section{Ml Macrothink}

International Journal of Education

ISSN 1948-5476

2014, Vol. 6, No. 4

Table 2 shows that there is a statistically significant difference between the means of the control and the experimental groups in the achievement post-test, where calculated $(\mathrm{T})$ has statistical significance at the level of significance $(\alpha<0.05)$. This difference is in favor of the experimental group that studied mathematics using smart board, where the mean of the experimental group was (22.78), while the mean of the control group was (18.59). The previous result shows that the first hypothesis of the study is rejected.

8.3 The results related to the second question: What is the effect of using smart board on mathematics retention of seventh grade students?

To answer the second question of the study, the retention test was applied to both the control group and the experimental group. Means and standard deviations were calculated, then T-test for independent samples was used, the following results have been reached and illustrated in table 3 .

Table 3. The results of T-test for independent samples to compare between the means of the control and the experimental groups in the retention test

\begin{tabular}{ccccccc}
\hline Group & Number & Mean & $\begin{array}{c}\text { Std. } \\
\text { Deviation }\end{array}$ & $\begin{array}{c}\text { Degree } \\
\text { of } \\
\text { freedom }\end{array}$ & $\begin{array}{c}\text { Value } \\
\text { of (T) }\end{array}$ & $\begin{array}{c}\text { Statistical } \\
\text { significance }\end{array}$ \\
\hline Control & 51 & 16.03 & 6.95 & 101 & 2.892 & $0.001 *$ \\
Experimental & 52 & 19.84 & 6.41 & & & \\
\hline
\end{tabular}

* Of statistically significant at $\alpha<0.05$

Table 3 shows that there is a statistically significant difference between the means of the control and the experimental groups in the retention test, where calculated (T) has statistical significance at the level of significance $(\alpha<0.05)$. This difference is in favor of the experimental group that studied mathematics using smart board, where the mean of the experimental group was (19.84), while the mean of the control group was (16.03). The previous result shows that the second hypothesis of the study is rejected.

\section{Discussion}

The results of the study revealed a positive effect of using smart board on students' achievement and retention in mathematics. The researchers found that this might be due to the following reasons:

- Mathematics teachers are able to do many things on the smart board to make learning mathematics more interesting such as making slides show, using internet, draw pictures and executing mathematical games.

- Students feel comfortable using a smart board and they are listing, hearing and are engaged during a lesson using a smart board, and using smart board helps students to be more 
fun and motivating in mathematics lesson.

- Visual representation on the smart board helps students to understand and remember mathematical information.

- Using smart board in teaching mathematics helps students to participate more in class discussions, enables them to stay on task better, helps them to express their thoughts better, and enables them to be more creative.

\section{Recommendations}

In light of the study results, the following recommendations are proposed:

- Encouraging the educational administration to provide all governmental schools with smart boards, and provide the teachers with the needed training to use the smart board in the classroom.

- Doing more researches to reveal the effect of using smart board on other variables other than mathematics achievement and retention such as: the ability of solving mathematical problem, mathematical thinking and attitudes toward mathematics.

- Doing more researches to reveal the effect of using smart board in teaching other subjects other than mathematics and for different grades.

- Doing more researches on the achievement and retention in mathematics such as: developing teaching methods and assessment techniques to enhance the students' achievement and retention in mathematics.

\section{References}

Aytac, T. (2013). Interactive whiteboard factor in education: Students' points of view and their problems. Educational Research and Reviews, 8(20), 1907-1915.

Bell, M.A. (2002). Why use an interactive whiteboard? A baker's dozen reasons! Teachers Net Gazzette, 3(1). Retrieved from http://teachers.net/gazette/JAN02/mabell.html

Burden, K. (2002). Learning from the bottom up - the contribution of school based practice and research in the effective use of interactive whiteboards for the FE/HE sector. Retrieved from www.lsda.org.uk/files/lsda/regions/8_Bio_KBurden.pdf

Carbonara, D. (2005). Technology literacy applications in learning environments. London, UK Information Science Publishing. http://dx.doi.org/10.4018/978-1-59140-479-8

Digregorio, P., \& Sobel-Lojeski, K.(2010). The effects of interactive whiteboards (IWBs) on student performance and learning: A literature review. Educational technology systems, 38(3), 255-312. http://dx.doi.org/10.2190/ET.38.3.b

Gregory, S. (2010). Enhancing student learning with interactive whiteboards: Perspective of 
teachers and students. Australian Educational Computing, 25(2), 31-34.

Hall, I., \& Higgins, S. (2005). Primary school students' perceptions of interactive whiteboards. Journal of Computer Assisted Learning, 21, 102-177. http://dx.doi.org/10.1111/j.1365-2729.2005.00118.x

Hall, K., Higgins, S., \& Smith, H. (2005). The visual helps me understand the complicated things: Pupil views of teaching and learning with interactive whiteboards. British Journal of Educational Technology, 36, 851-867. http://dx.doi.org/10.1111/j.1467-8535.2005.00508.x

Kersaint, G. (2007). Toward technology integration in mathematics education: A technology integration course planning assignment. Contemporary Issues in Technology and Teacher Education, 7(4), 256-278.

Knezek, G., Christensen, R., Bell, L., \& Bell, G. (2006). National technology leadership summit re-port: Identifying key research issues. Learning and Leading with Technology, 33(8), 18-23.

Li, Q. (2003). Would we teach without technology? A professor's experience of teaching mathematics education incorporating the internet. Educational Research, 45(1), 61-77. http://dx.doi.org/10.1080/0013188032000086127

Manitoba Education \& Training. (1998). Technology as a foundation skill area: A journey toward information technology literacy. Retrieved from http://www.edu.gov.mb.ca/k12/docs/support/tfs/index.html

Miller, D., \& Glover, D. (2002). The interactive whiteboard as a force for pedagogic change: The experience of five elementary schools in an English Education Authority. Information Technology in Childhood Education Annual, 14, 5-19.

National Council of Teachers of Mathematics - NCTM. (2000). Principles and Standards for Mathematics. Reston, Virginia.

Niess, M. L. (2006). Guest Editorial: Preparing teachers to teach mathematics with technology. Contemporary Issues in Technology and Teacher Education, 6(2), 195-203.

Oigara, J. N. (2010). Integrating tools of technology into teaching social studies methods courses: A class-room example, In D. Gibson \& B. Dodge (Eds.). Proceedings of Society for Information Technology \& Teacher Education International Conference (pp. 3682-3684). Chesapeake, VA: AACE.

Oigara, J. N., \& Keengwe, J.(2011). Pre-service teachers and technology integration with smart boards. Journal of Information Communication and Technology Education, 7(4), 84-92. http://dx.doi.org/10.4018/jicte.2011100108

Rakes, G. C., Flowers, B. F., Casey, H. C., \& Santana, R. (2006). Analysis of instructional technology use and constructivist behaviors in K-12 teachers. International Journal of Educational Technology, 1(12). 
Reimer, K., \& Moyer, P.S. (2005). Third-graders learn about fractions using virtual manipulatives: A classroom study. Journal of Computers in Mathematics and Science Teaching, 25, 5-25.

Roschelle, J., Pea, R., Hoadley, C., Gordin, D., \& Means, B. (2000). Changing how and what children learn in school with computer-based technologies. The Future of Children: Children and Computer Technology, 10(2), 76-101. http://dx.doi.org/10.2307/1602690

Rudd, T. (2007). Interactive whiteboards in the classroom. Retrieved from www.futurelab.org.uk/events/listings/whiteboards/report

Sani, R. (2007). Creative means to bridge old and new teaching. Arizona State University. Retrieved from http://tnt.asu.edu/files/Smartboards_Newsletter_Aug.pdf

Shenton, A., \& Pagett, L. (2007). From 'bored' to screen: The use of the interactive whiteboard for literacy in six primary classrooms in England. Literacy, 41(3), 129-136. http://dx.doi.org/10.1111/j.1467-9345.2007.00475.x

Siemens, G., \& Matheos, K. (2010). Systemic changes in higher education. Education: Technology \& Social Media (Special Issue, Part 2), 16(1). Retrieved from http://www.ineducation.ca

Smart Technologies Inc. (2004). Interactive whiteboards and learning: A review of classroom case studies and research literature. Retrieved from http://www.smarterkids.org/research

Starkman, N. (2006). The wonders of interactive whiteboards: No cutting-edge classroom is complete without one. T H E Journal, 33(10), 36-39.

Torff , B., \& Tirotta, R. (2010). Interactive whiteboards produce small gains in elementary students' self-reported motivation in mathematics. Computers \& Education, 54, 379-383. http://dx.doi.org/10.1016/j.compedu.2009.08.019

Wall, K., Higgins, S., \& Smith, H. (2005). 'The visual helps me understand the complicated things': Pupil views of teaching and learning with interactive whiteboards. British Journal of Educational Technology, 36, 851-867. http://dx.doi.org/10.1111/j.1467-8535.2005.00508.x

\section{Copyright Disclaimer}

Copyright for this article is retained by the author(s), with first publication rights granted to the journal.

This is an open-access article distributed under the terms and conditions of the Creative Commons Attribution license (http://creativecommons.org/licenses/by/3.0/). 